Article

\title{
The Impact of Brexit on EU Trade Policy
}

\author{
Ferdi De Ville ${ }^{1, *}$ and Gabriel Siles-Brügge ${ }^{2}$ \\ ${ }^{1}$ Centre for EU Studies, Ghent University, 9000 Ghent, Belgium; E-Mail: ferdi.deville@ugent.be \\ 2 Department of Politics and International Studies, University of Warwick, Coventry, CV4 8UW, UK; \\ E-Mail: g.siles-brugge@warwick.ac.uk \\ * Corresponding author
}

Submitted: 22 March 2019 | Accepted: 3 July 2019 | Published: 16 September 2019

\begin{abstract}
There has been increased interest in trade policy following the UK's EU membership referendum. However, relatively little scholarly analysis has been produced on how Brexit will affect EU trade policy. Instead, the received wisdom has been that Brexit will shift the EU's trade policy position in a less liberal direction. This is based on a 'static' analysis where the UK variable is simply removed from the figurative 'function' determining EU trade policy. We argue that this neglects the potential role of more 'dynamic' effects. First, the negotiations to determine the nature of the EU-UK future economic partnership are likely to involve a lengthy process with a still uncertain, and possibly evolving, destination. The outcome and process of arriving there will influence how economic operators and policymakers adapt their preferences and behaviour, including through possible relocation and the formation of new alliances. This will shape EU trade policy in potentially counterintuitive ways. Second, the absence of clear material structures from which actors can 'read' their interests highlights the importance of considering the role of ideas and political framing. How the vote for and consequences of Brexit are interpreted will likely shape what is considered an appropriate policy response. Examining EU trade policy since the Brexit vote, the article finds that rather than push the EU in a more illiberal direction, the referendum result has been used to reinforce the European Commission's external liberalisation agenda. The Commission's discursive response to Brexit and Donald Trump has been to portray the EU as a champion of free trade in an era of global populism.
\end{abstract}

\section{Keywords}

Brexit; discourse; dynamic effects; European Union; trade policy; United Kingdom; uncertainty

\section{Issue}

This article is part of the issue "The Impact of Brexit on EU Policies", edited by Ferdi De Ville (Ghent University, Belgium) and Gabriel Siles-Brügge (University of Warwick, UK).

(C) 2019 by the authors; licensee Cogitatio (Lisbon, Portugal). This article is licensed under a Creative Commons Attribution 4.0 International License (CC BY).

\section{Introduction}

Trade policy has been a central focus of academic and policy debates concerning the consequences of Brexit. However, existing analyses have primarily concentrated on the shape of the future EU-UK trade and economic relationship and the challenges facing the UK as an independent trade policy actor (e.g., Hestermeyer \& Ortino, 2016; Trommer, 2017). Where there has been a consideration of the impact of Brexit on EU trade policy, the conventional wisdom has been that the loss of a proliberalisation Member State will push the EU in a more 'protectionist' direction. For example, a recent Chatham House research paper on transatlantic trade relations invokes 'internal fissures within the EU' between proliberalisation and more defensive Member States. It argues that the 'loss of a significant pro-free-trade voice within the bloc...also has consequences for the EU's ability to speak with one voice in [ongoing] negotiations with the US' (Schneider-Petsinger, 2019, pp. 18-19).

Such assessments assume that EU trade policy can simply be analysed as an 'equation' from which the UK variable can be removed (Jensen \& Snaith, 2018, p. 255). They have taken the UK's historical record as a liberal 
Member State and concluded that Brexit will shift EU trade policy in a more protectionist direction. We see this as being a 'static' analysis in two senses, drawing on understandings of the term in economic analysis (this supplements the discussion in De Ville \& Siles-Brügge, 2019). Firstly, static can refer to the underlying assumption that the preferences and behaviour of relevant actors in response to Brexit remain unchanged. Secondly, and analogous to comparative static analysis, existing accounts have compared pre- and expected post-Brexit equilibria without examining the adjustment path itself. In our view this remains an incomplete view of the effects of Brexit, even if one were to change the parameters of static analysis by, for example, adjusting the degree to which the UK was a liberal presence within the EU. In arguing for a more dynamic account, we consider not only general adjustments in the behaviour of relevant actors but also specifically those resulting from the political process of negotiating the UK's exit. We also argue that these actors' preferences and strategies are significantly influenced by the way in which the causes and consequences of the Brexit vote are discursively constructed.

This all follows from the emphasis we place in the next section on seeing the negotiation of EU-UK trade arrangements as a process with an indeterminate and uncertain end point. After critically discussing in Section 3 how a static analysis might assess the impact of Brexit on the EU's trade policymaking institutions, market power and configuration of societal interests, Section 4 considers how this needs to be overlaid with an appreciation of how institutional and societal actors are likely to adjust their behaviour in response to different Brexit outcomes and their negotiation. Contrary to expectations, a harder Brexit may in fact not strengthen the relative position of protectionist interests in the EU given that proliberalisation UK-based businesses will be more probable to relocate to the EU27. Even under a soft Brexit, which is more likely to lead to a shift in the interest constellation in EU trade policy as UK-based firms are less likely to relocate but cease being represented by the EU27, continued high levels of interdependence between EU27 and UK firms might mean pro-liberalisation interests retain influence over EU trade policy. The absence of clear material structures from which actors can unproblematically 'read' their material interests also puts a premium on the role of ideas in shaping responses to Brexit (Blyth, 2003; De Ville \& Siles-Brügge, 2019). Section 5 therefore considers the discursive battle over the interpretation of the referendum result that has taken place since the referendum. It finds that Brexit has counterintuitively reinforced the EU's liberal trade policy orientation over this period. Section 6 concludes.

\section{Uncertainty over the Future Economic Partnership}

As noted in the editorial for this thematic issue, the shape of the post-Brexit UK-EU economic arrangement is yet to be determined. Not only are several potential outcomes still in play but there is also a potentially lengthy and unstable process of arriving there. This might entail a transition and activation of the Irish 'backstop' as well as a further extension of Article 50. Two extensions have already been granted at the time of writing (July 2019), with the latest lasting until the end of October 2019. While these 'temporary' outcomes may themselves also become more permanent than intended (see Henig, 2018), they are still likely to be politically unstable given divisions within the UK and EU on the future state of relations. These are most clearly evidenced by UK cabinet battles over whether to align with the EU regulatory and customs regime and Member State disagreements over granting the UK an Article 50 extension.

As a result, the future economic partnership needs to be thought of not only in terms of the degree of economic integration it implies between the EU27 and the UK, but also in respect of its stability. The latter is understood here simply in terms of the expected longevity of the agreement and its degree of institutionalisation, in other words: whether it is described as temporary or permanent and whether it features a legally-binding agreement or not. There may be other domestic and international factors affecting the stability of various agreements, but we do not consider these here for reasons of space and parsimony.

Figure 1 maps several of the mooted options for a future EU-UK relationship in terms of these two dimensions. The bottom left quadrant inhabited by 'No Deal' gives us the least stability. It is not intended to be permanent and it would entail no agreement between the EU and UK, pace talk of a 'managed No Deal'. It also gives us the least economic alignment, with trade taking place on the 'most-favoured-nation' terms available to the entirety of the World Trade Organization (WTO) membership. In contrast, the top-right quadrant inhabited by the European Economic Area (EEA)(+) option would be the most stable and economically integrated arrangement. It would involve either just membership of the EEA-short-hand for the Single Marketor membership supplemented with a full customs union $(E E A+)$. In between these two options lies the 'backstop' option in the EU-UK WA, which would entail a customs union between GB and the EU with some 'level playing field' provisions on 'flanking policies' covering state aid, the environment and labour rights. The backstop would provide a medium degree of economic integration, but only for goods. Despite its formally openended nature it is described as being merely an insurance policy or, at the very most, a temporary measure until it can be 'superseded' by a 'subsequent agreement' (Article 2 of the Protocol on Ireland/Northern Ireland). The Comprehensive Economic and Trade Agreement $($ CETA)(+) option, in turn, would involve a Free Trade Agreement (FTA) such as the one between the EU and Canada-or with supplemental liberalisation provisions (CETA[+] would be available for GB only, see Figure 1 notes). This implies a comparatively lower degree of inte- 


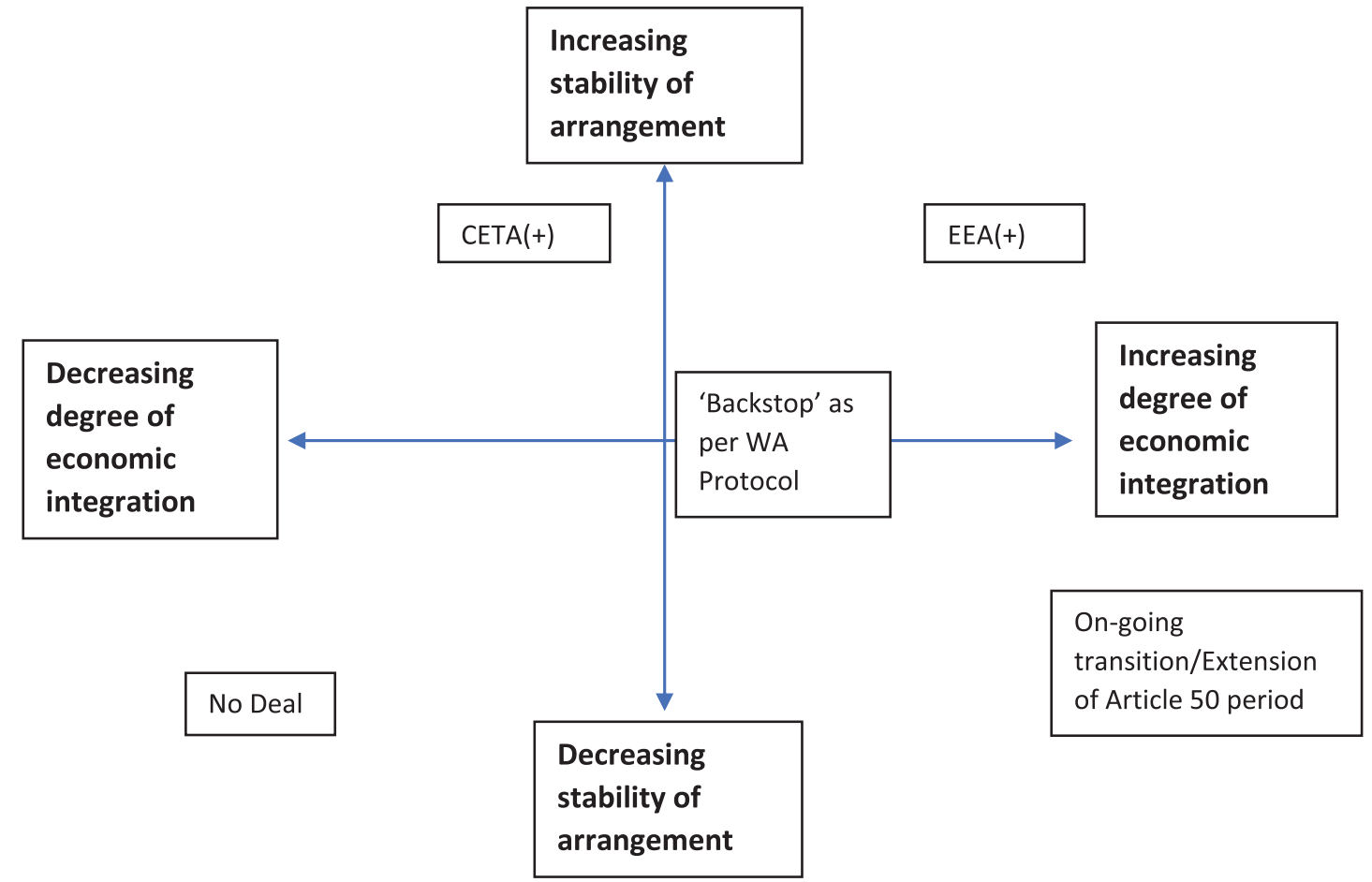

Figure 1. The level of economic integration and stability of the EU-Great Britain economic relationship. Notes: The various arrangements are considered for Great Britain only. The EU27 have so far insisted that to preserve an open border in Northern Ireland, different arrangements may have to apply to this part of the UK, as operationalised in the 'backstop' included in the Withdrawal Agreement (WA). Source: authors' elaboration.

gration, but on a more stable footing. Finally, the 'transition period' would be the most economically integrated of the options but is only intended to be temporary; the WA stipulates an end date of December 2020, with a possible extension of one or two years. Alternatively, Brexit could at the time of writing also entail a further, supposedly temporary extension of the Article 50 process lasting anything from a few months to several years.

Figure 1 forces us to consider not just an end state of EU-UK talks on a Future Economic Partnership but also the process of arriving there. It factors in the instability of potentially enduring arrangements intended for the 'interim' or as 'insurance', namely the transition and the backstop. The few static analyses of Brexit's impact on EU trade policy that we consider next have, however, largely focused on simply subtracting the UK variable from the EU 'equation' (Jensen \& Snaith, 2018, p. 255), without considering how actors might dynamically adjust their behaviour, especially given such uncertainty. We return to this issue in Section 4.

\section{The Static Effects of Brexit on EU Trade Policy}

\subsection{Institutional Factors}

Focusing on static effects, several scholars have re-stated the conventional wisdom that Brexit could push the EU in a less liberal direction due to a shift in the balance of power between different institutional actors within its trade policy machinery (Jacobs, 2018, pp. 109-110; Jensen \& Snaith, 2018, p. 262; Larsen, 2018, p. 225). The loss of a traditionally liberal Member State, and its votes in the Council, is seen as 'mov[ing] the centre of gravity towards the more protectionist countries in the EU' (Larsen, 2018, p. 225). Such views would be consistent with seeing the so-called 'protectionist Southern bloc' of France, Italy and Spain gaining in prominence (see Zimmermann, in press).

Existing research based on recorded votes in the area of trade defence has shown that the UK has been amongst the Member States most frequently opposed to anti-dumping duties (Evenett \& Vermulst, 2005, pp. 711-712; Nielsen \& Svendsen, 2012, pp. 203-204). The UK has not had the most liberal voting record, as Scandinavian countries and the Netherlands have opposed anti-dumping measures even more consistently. But the departing Member State has been the key opponent of anti-dumping duties when assessed based on its relative weight. Representing 12.9 per cent of the current EU population, the UK's vote is much more significant than the share of Scandinavian and Dutch votes combined ( 7.55 per cent of the EU population; data from Council of the EU, 2019).

As Hubert Zimmermann (in press) notes, and the importance of relative vote shares begins to suggest, simply focusing on 'binary depiction[s]' of 'free traders vs. protectionists...neglects the complex process by which trade decisions are reached in the European Union'. Adopting 
a rational choice institutionalist approach focused on decision-making practices suggests that UK departure is thus less likely to have a major impact. Zimmermann (in press) broadly shares Alasdair Young's (2017b, p. 6) conclusion that Brexit's impact on the balance within the Council 'is unlikely to be very consequential'. This is even more relevant in areas other than trade defence, where formal voting in the Council is less common (see Woolcock, 2015, p. 401). In particular, and as Young (2017b, p. 6) highlights, decisions on trade negotiations are conducted 'on the basis of consensus (and for mixed agreements in the shadow of ratification by all member states)' (see also De Bièvre, 2018, p. 79).

Turning to inter-institutional battles, Henrik Larsen (2018, p. 225) has argued that Brexit may potentially facilitate the liberal Commission's role in trade policy by removing a sovereignty-conscious Member State from the Council. That said, the UK's position on the most recent EU trade policy competence battle over investor protection suggests that its role in constraining liberal, supranational trade and investment policies may be overstated. The UK was in the camp of Member States that supported the continued inclusion of Investor-State Dispute Settlement during the EU-US Transatlantic Trade and Investment Partnership (TTIP) negotiations (Oliver \& Spiegel, 2014).

Less discussed has been the role of the European Parliament (EP). The Parliament has been an increasingly 'assertive' actor within EU trade policymaking since the Treaty of Lisbon and, especially, the TTIP negotiations (Roederer-Rynning, 2017). Zimmermann draws a counterintuitive conclusion. Despite the loss of generally pro-liberalisation Labour and Conservative MEPs, with Labour playing a key role thanks to the king making position of the Group of Socialists \& Democrats, the significant presence of UKIP in recent years has meant that the UK's MEPs expressed a more critical view of trade liberalisation than the EP as a whole (Zimmermann, in press; see also Frantescu, 2015). Analysing 13 votes between 2015-2017, Zimmermann has found that in 10 cases the votes of the UK delegation were considerably more 'skeptical' of trade liberalisation than the Parliament as a whole. This was on key issues such as the TTIP negotiations, the approval of CETA, the opening of negotiations with Australia and New Zealand and talks at the WTO. On the other hand, of the UK's 73 seats in the $E P$, only 27 will be redistributed amongst other Member States if and when Brexit occurs. This includes a gain of 5 for France and Spain each, 3 for Italy and only 6 in total for the 'Northern European coalition' countries (Netherlands, Sweden, Denmark and Finland; EP, 2018). This redistribution of seats has led VoteWatch Europe (2018, emphasis omitted) to conclude, on the basis of nationally-based voting patterns on trade which mirror those of Member States in the Council, that 'protectionist forces are likely to gain more influence in the new European Parliament'. In sum, given that these factors point in opposing directions and that there is a compar- atively small number of MEPs involved, the expectation might be that there is likely to be little change post-Brexit in the EP.

\subsection{Market Size and the Domestic Configuration of Interests}

While static analyses have thus emphasised a possible, albeit limited, anti-liberalisation shift in the institutional balance of power as a result of Brexit, several authors have suggested that it will have a significant impact on the EU's market size and consequent negotiating leverage (Jensen \& Snaith, 2018, p. 262; Khorana \& García, 2018, pp. 9-10; Young, 2017a, p. 112, 2017b, p. 6). The UK represents 16 per cent of the Gross Domestic Product of the Union. As a result, some have argued that the EU will become less prone to make the more onerous concessions likely to be asked of it in order to secure trade agreements (Young, 2017a, p. 112). Others have suggested that the EU could become more commercially minded and less likely to leverage market access to achieve other foreign policy objectives (Khorana \& García, 2018, p. 10).

What of the UK as a component of the EU's trade and what this says about the post-Brexit configuration of interests in the EU? Figure 2 shows the revealed comparative advantage in goods and services of the UK relative to the EU, using data from 2017. This is calculated by dividing the share of total exports of a certain goods or services category for the UK by the share of total exports for that same category for the EU28. It illustrates the relative specialisation of the UK's goods and services exports compared to the EU as a whole, with a value above 1 indicating that the UK is relatively more specialised in a particular sector. Our analysis, which is in line with an earlier UK Government study based on data for 2010 (Department for Business, Innovation \& Skills, 2012), demonstrates that the UK is predominantly specialised in services exports, notably insurance, pension and (other) financial services. The UK exports relatively few primary products-such as agricultural goods or minerals-or lower-skill manufactured products-such as textiles and clothing or metal products.

This overall pattern of specialisation is also reflected in the overall negative balance for trade in manufactures (Perraton \& Spreafico, 2019). Although some manufacturing, such as motor vehicles, has benefitted from substantial inward investment, this has often been focused on assembly in transnational supply chainswith low domestically manufactured content (Berry, 2016, pp. 38-39; Froud, Johal, Law, Leaver, \& Williams, 2011, pp. 30-31). This economic structure has been actively promoted by successive UK Governments through an 'Anglo-liberal' growth model (see Hay, 2011). Scott Lavery, Lucia Quaglia and Charlie Dannreuther (2019, p. 253) have highlighted how the 'UK economy is underpinned by a distinctive "national business model", organised around a dominant financial sector, flexible 


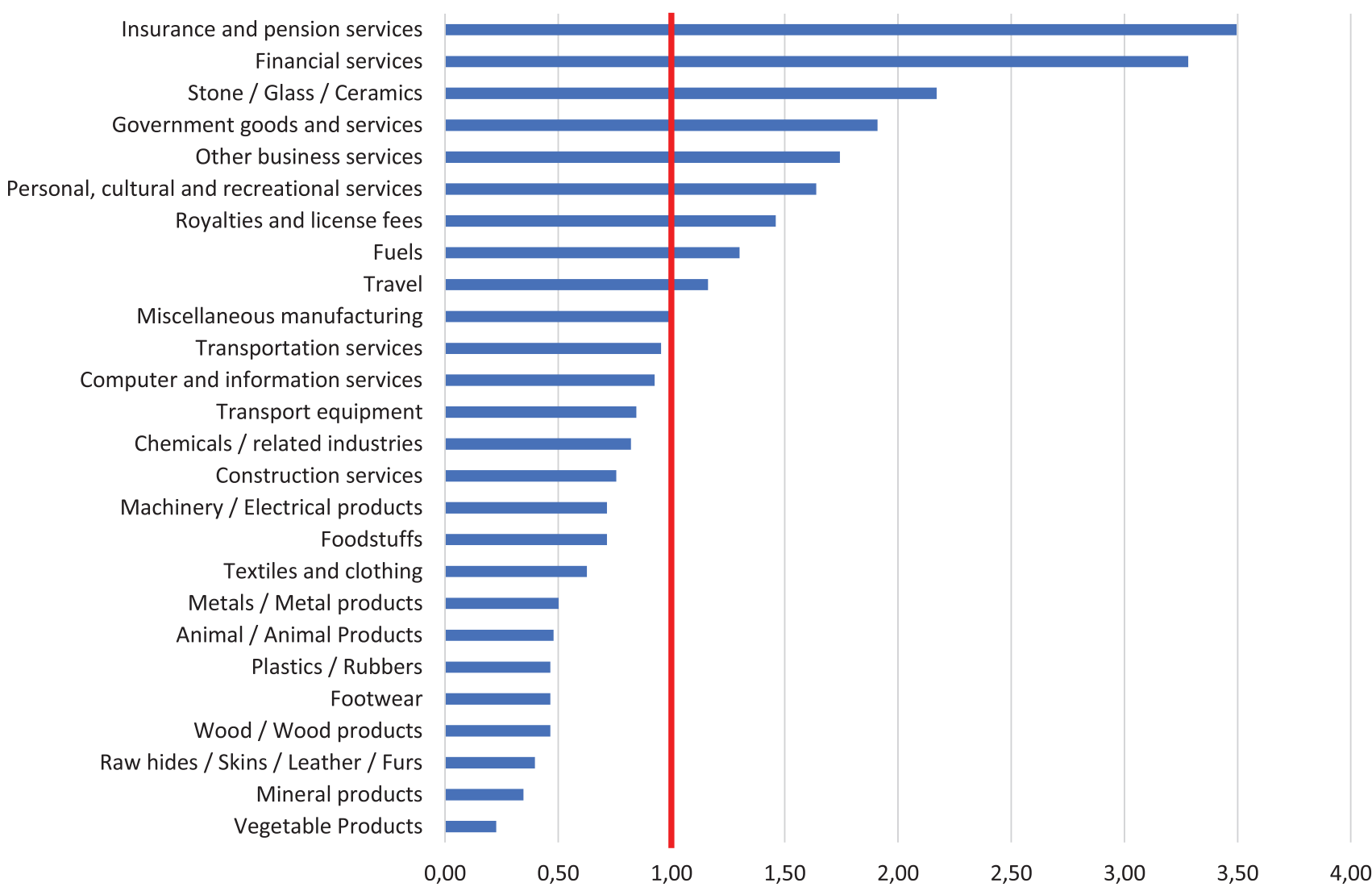

Figure 2. UK revealed comparative advantage relative to the EU28 (2017). Sources: authors' calculations based on data from UN Comtrade for international trade in goods (using WITS software) and the Organisation for Economic Co-operation and Development for international trade in services.

labour market, service-led growth and openness to international capital flows'.

While such analyses might underplay the interplay between goods and services in the UK's (and other countries') exports often highlighted in economic and policy debates (e.g., Cernat \& Kutlina-Dimitrova, 2014; International Trade Committee, 2019), they still point to the comparatively prominent role that promoting (financial) services and certain types of inward investment have played in shaping government decision-making. UK services interests have also been well-represented in the EU's trade policy by both the UK Government and the European Commission (Lietaert, 2009; Van Loon, 2018). With Brexit, a static analysis based on subtracting the UK from the EU might therefore suggest that the EU will be less interested in pursuing external services liberalisation than it has been to date. Instead, it would become more driven by the interests of its industrial and agricultural sectors, whose interests will be more likely to vary depending on the trade partner concerned (on the UK's role as a driver of liberalisation in agricultural trade, see Roederer-Rynning \& Matthews, 2019). That said, one persistent area of UK defensiveness in services and investment negotiations in recent years has been the issue of General Agreement on Trade in Services 'mode 4 ' services liberalisation, the natural movement of persons to deliver a service, given its association with immi- gration policy. This was one of the key stumbling blocks in FTA negotiations with India (see Siles-Brügge, 2013, pp. 608-609). These tensions in the British position in respect of trade in services are further grist to the mill that as a Member State the UK has acted as a 'pivotal outlier' in shaping EU policy positions (De Ville \& Siles-Brügge, 2019; Smith, 2019).

\section{Towards a More Dynamic View of Brexit's Effects on EU Trade Policy}

The only 'known known' about Brexit, assuming it does occur, is the fact that the UK will lose formal representation in the EU Institutions. Even if there is an extension to the Article 50 period the UK and its representatives in the Council and EP will have lost much of their leverage in internal negotiations, in what De Ville and Siles-Brügge (2019) call 'anticipatory adjustment'. Static analysis might therefore seem appropriate to studying the impact that Brexit has on the institutions of EU trade policy. As noted above, these explanations suggest limited change in a potentially more protectionist direction. Even here, however, Brexit may be a source of dynamic trade policy impacts. For one, the UK may benefit from new institutional mechanisms that afford it indirect influence in EU trade policy. This could go from formalised consultation mechanisms if it was part of a customs 
union (Lowe, 2018a) to influence on the EU's domestic regulations via formalised regulatory cooperation processes (see De Ville \& Siles-Brügge, 2016). Existing precedents suggest that the latter is much more likely than the former. Secondly, Brexit can lead to the reconfiguration of voting coalitions in the EU Institutions. Notably, following the EU referendum, the 'New Hanseatic League' has emerged as a Member State coalition composed of the fiscally-conservative and pro-liberalisation Netherlands, Ireland, Nordic and Baltic states. It aims to counterbalance the strengthened and less economically liberal Franco-German axis (see Khan, 2018).

More generally, and as the discussion in Section 2 highlighted, assessing Brexit's impact is not simply a question of subtracting the UK's market size and economic interests from that of the EU's. Rather, we must consider how the negotiation of a future economic arrangement could unfold and the impact this process has on the behaviour of relevant actors, including firms.

\subsection{The Dynamics of Relocation}

The behaviour of economic operators is likely to have an important impact by reshaping the EU's domestic configuration of interests. Taking a dynamic approach to the question of the (re)configuration of EU interests leads us to focus on how the Brexit process shapes the degree to which UK-based firms offshore their production/servicedelivery to the EU27. This is because the UK would face considerable difficulties pursuing an even more lowtax/low-regulation business model as a means of retaining/attracting investment (Seabrooke \& Wigan, 2017). While more alignment (the right-most quadrants of Figure 1) would on its own imply less movement of UK-based firms and investment to the EU, this is not the only factor at play. Ceteris paribus, a less stable arrangement (the bottom quadrants of Figure 1) would imply more offshoring from the UK to the EU given increased uncertainty over the future arrangement.

There is already evidence of referendum-induced uncertainty leading to this kind of anticipatory adjustment in the investment decisions of firms. For one, there has been evidence of reduced investment in the UK. One 2018 study using the fDi Markets database, which focuses on greenfield Foreign Direct Investment (FDI), estimated that the number of FDI projects in the UK declined by $16-20$ per cent with respect to what might have been expected without the vote for Brexit. The authors also found that inward FDI flows declined the most in services (by 25 per cent), potentially pointing to the sunk nature of investments in manufacturing (Serwicka \& Tamberi, 2018 , pp. 1, 9). In addition, there is also evidence of such reduced investment being a sign of the offshoring of economic activities from the UK to the EU27. Counting both mergers and acquisitions and greenfield activity, a 2019 study estimated that the Brexit vote had led not only to an 11 per cent decline in UK inward investment flows from the EU27, but also to an increase of 12 per cent in investment by UK firms in the EU27. This increase in investment by UK firms came 'entirely from higher investment by the services sector' (Breinlich, Leromain, Novy, \& Sampson, 2019, p. 2). More recent analysis of data from the fDi Markets database by the Financial Times has also found evidence of FDI flows not only declining, but also shifting from the UK to the EU27. In the three years to the first quarter of 2019 greenfield FDI flows into the EU27 increased by 43 per cent compared to the previous three-year period (Q1 2013-Q1 2016). The UK, in turn, experienced a 30 per cent decline. Of the 474,000 EU27 additional jobs created over this period compared to the previous three years, 53,000 were said to come from UK companies investing in the EU (Romei \& Jackson, 2019).

The ultimate impact of any reconfiguration of interests, of course, will vary between sectors and the specifics of the different post-Brexit EU-UK arrangements. Additionally, as Egan (2019) highlights, the degree of integration across the EU's Single Market varies, including between goods and services. Given the UK's political economic model (see above), two groups stand out as being particularly likely to relocate in the event of a hard Brexit and/or prolonged uncertainty. Firstly, there are those firms most reliant on EU 'freedoms' to deliver cross-border services. Cross-border activities feature much more prominently as a mode of supply for UK firms exporting services to the EU27 than to the rest of the world (Lowe, 2018b, pp. 10-11). This includes, but is not limited to, financial services firms making use of 'passporting' arrangements. These are likely to relocate at least some of their activities to the EU27 (Howarth \& Quaglia, 2017, p. 161; Zimmermann, in press). One estimate from consultancy EY puts the number of City jobs to move to the EU27 at around 7000 (Morris, 2019). The second group of highly affected business is that of firms in manufacturing supply chains reliant on 'just in time production' such as a the automotive, aerospace and pharmaceutical sectors. These are likely to be hit by the end of 'frictionless trade' (see Egan, 2019). Given the sunk nature of investments in manufacturing, this might mean relocation is delayed when compared to services, as the data above suggests, but still more likely to happen in the event of prolonged uncertainty or a harder Brexit. For example, inward investment flows in the UK automotive sector already nearly halved between 2017 and 2018 (Hotten, 2019). Of the permanent options in Figure 1 above, only the EEA+ would potentially preserve frictionless trade for manufacturers. An FTA would entail regulatory and customs checks for compliance with rules of origin requirements and the backstop customs union, at least on its own, would entail not just regulatory checks but also paperwork to certify that goods were eligible for free circulation.

Offshoring from the UK to the EU27 would interact with the only certainty of Brexit, a loss of UK votes in the EU Institutions, or a significant lessening of the influence of British representatives in the case of an Article 50 extension. We might expect an outcome in the 
top-right quadrant of Figure 1 such as the EEA+ to imply the least change to the EU's trade policy as the EU's market size would be unaffected. However, it would also lessen the pressure for firms to relocate both because of continued alignment and reduced uncertainty. As a result, it would also be the most likely to change the EU27's internal balance of interests. Given no formal UK involvement in EU trade policymaking, the configuration of firms present in the EU27 and thus represented by the Member States, MEPs and through European/national lobby groups would change with respect to the preBrexit situation. The UK's services and global/regional value chain-reliant manufacturing exporters would no longer be directly represented. These interests have contributed to rendering the UK a liberal 'pivotal outlier' in EU trade policy in the past. This might suggest less of a willingness on behalf of the EU to make market access concessions in areas such as agriculture or import-competing manufacturing, given that these interests would gain in relative representation. Meanwhile, the EU27 would still be able to offer access to the UK market given customs and regulatory alignment.

That said, under a softer Brexit, levels of interdependence between EU27 and UK firms would likely remain high. Existing supply chains are more likely to be preserved, contributing to continued high levels of intrafirm trade and investment flows between both parties. The political effects of this might be to encourage alignment in the positions on trade policy adopted by some EU27 and UK economic interests as occurred during the EU-US TTIP negotiations. Here businesses formed transatlantic alliances to lobby in favour of the agreement as a result of the high levels of economic interpenetration across the Atlantic (Young, 2017a, pp. 57-59). This might mitigate some of the anti-liberalisation effects of a reduced presence of pro-liberalisation economic actors in the EU27-albeit likely not all given the UK's outlying role in EU trade policymaking.

Such '21st century trade politics' (Young \& Peterson, 2014) is premised on the very economic interdependence driving business relocation in the event of a harder Brexit or prolonged uncertainty (the outcomes in the left and bottom quadrants of Figure 1). As firms plugged into regional and global supply chains-and/or otherwise interdependent with European and global firms-relocate to the Union, the balance of views represented within the EU27 in such a scenario would be less likely to change significantly than in the event of a soft or more certain Brexit.

There remains the question of how any relocated foreign investments or external business actors would be viewed politically in the EU, particularly following concerns in Member States over Chinese investment in debates over investment screening (Meunier, 2014) or US investment in the negotiations concerning investor protection in TTIP (Siles-Brügge, 2017). In the UK, meanwhile, business concerns have been largely side-lined in the internal battles over the future EU-UK arrange- ments (see, for example, James \& Quaglia, 2019). EU trade policy, however, is in a very different state to UK politics, sovereignty-based concerns over inward investment notwithstanding. As Section 5 will illustrate, the European Commission continues to be a predominantly liberal trade policy actor. It remains committed to the sentiment expressed in its most recent trade strategy (Trade for All from 2015) that investment and global value chains are key to EU prosperity (European Commission, 2015, p. 9). The Commission also has a history of seeking support from exporters in pushing for trade liberalisation, even helping with the establishment of a European-level services lobby group, the European Services Forum (Lietaert, 2009, pp. 12-17). While it therefore remains to be seen what influence any relocated investors wield within EU trade policymaking, there is a strong chance they will strengthen the hands of those pushing for a liberal trade policy. This is particularly the case if Brexit is successfully framed as an illegitimate, protectionist step-as appears to be occurring (see Section 5). Certain EU Member States have also been very vocally courting the relocation of UK businesses (e.g., in financial services).

In sum, continued interdependence (in the event of a soft Brexit/less uncertainty) and/or relocation (in the event of a hard Brexit/more uncertainty) are likely to mean pro-liberalisation interests continue having an important presence in the EU regardless of the shape of post-Brexit arrangements. The exact pattern of relocation will depend not just on the final outcome but on the ongoing Brexit process underpinned by uncertainty, underscoring the importance of focusing on dynamic, rather than static, impacts.

\subsection{International Negotiating Dynamics}

Figure 1 also provides some guidance as to the dynamic effects that Brexit might have on the EU's international negotiating leverage. For one, the size of the EU's market may well not shrink in the case of outcomes in the right-most quadrants. This would help to maintain the EU's direct 'market power' (Damro, 2012) and the indirect power of the 'Brussels effect' where EU market rules are unilaterally adopted by third parties (Bradford, 2012). However, this may be as a result of inherently unstable arrangements that nevertheless diminish EU negotiating leverage, such as in the cases of an on-going transition, backstop or Article 50 extension. Moreover, EU negotiating capital will have to be expended clarifying the EU27's schedules at the WTO (on the foreign policy consequences of these negotiations, see Smith, 2019). This will not only be the case for arrangements in the leftmost quadrants, but also for supposedly temporary outcomes such as the proposed transition/Article 50 extension. It is especially relevant for tariff-rate quotas for sensitive goods such as agricultural and fisheries products, which will need to be reapportioned between the EU27 and the UK post-Brexit. This issue potentially also arises 
in the context of the EU's existing FTAs with third parties. The EU may wish to re-open discussions in order to not have to absorb an existing quota entitlement negotiated while the UK was still a member (International Trade Committee, 2018, pp. 19-20). Meanwhile, the greater and more stable the degree of economic alignment between the UK and the EU, the less likely the UK is to emerge as a trade policy competitor vying for market access with the EU, insofar as any independent trade policy competence is constrained. This dynamic is particularly relevant in the area of services and investment liberalisation where there are 'first-mover' advantages (see Manger, 2009).

Having considered one set of dynamic effects that are dependent not only on the future EU-UK arrangement but also on the process of arriving there, we now turn to the discursive impact that Brexit is already having on EU trade policy since the referendum.

\section{Brexit's Impact on EU Trade Discourse and Practice So Far: Reinforcing the Status Quo}

EU trade discourse and practice has been characterised as following a broadly liberal trajectory, certainly since the early 1990s (see De Ville \& Siles-Brügge, 2018). This liberal core of EU trade policy has been complemented by two other elements. The first has been a stress on the need to protect EU firms and workers against 'unfair trade', in part to maintain domestic support for trade liberalisation (see Bollen, De Ville, \& Orbie, 2016). The second has been an ambition to use trade policy as a foreign policy instrument (see Meunier \& Nicolaïdis, 2006; Young \& Peterson, 2014).

For long, this essentially liberal position was relatively uncontested. This changed with the EU-US TTIP negotiations, which resulted in 'unprecedented debate' on trade policy within the EU (see De Ville \& SilesBrügge, 2016). The contestation of trade policy led the Commission to make some changes to both substance and process, notably with respect to investor protection and transparency (see Gheyle \& De Ville, 2017; SilesBrügge, 2017). In its most recent trade policy strategy Trade for All dating from October 2015, the Commission recognised that it had to '[adapt] its approach to trade policy to take all of these lessons [from TTIP] on board' (European Commission, 2015, p. 5). However, notwithstanding the more balanced tone about the objectives of trade policy, the new strategy was hardly revolutionary. In line with the EU's trade policy trajectory since the 1990s, it continued advocating trade liberalisation. This was described as even more important given the rise of 'global value chains', which are mentioned no fewer than fourteen times in the document. In the words of the Commission '[g]lobal value chains mean trade policy can no longer be approached from a narrow mercantilist angle' (European Commission, 2015, p. 10).

Hence, in the run-up to the Brexit referendum the EU's 'broadly liberal' trade policy had been significantly challenged in the context of the TTIP negotiations-but not been radically altered in response. Advocates of the EU's liberal trade policy orientation succeeded in framing the contestation of TTIP as demonstrating the need for better communication regarding the benefits of FTAs and for limited procedural and substantive changes. Would the UK's referendum outcome destabilise the EU's longstanding trade policy position more fundamentally?

As De Ville and Siles-Brügge (2019) underscore in the editorial for this thematic issue, a discursive struggle on how to interpret Brexit has not only quickly kicked off in the UK but also in the remaining EU27. In March 2017, the European Commission weighed in on this debate through its White Paper on the Future of Europe in which it outlined five possible scenarios for the EU27 (European Commission, 2017a). This was followed by five thematic reflection papers. The Reflection Paper on Harnessing Globalisation is primarily concerned with the future of EU trade policy (European Commission, 2017b). Rather than framing Brexit as a development requiring a fundamental rethink of trade policy-for example, by gearing it much more towards protecting the losers of globalisation'-it is very much in line with the EU's prereferendum Trade for All strategy.

The paper starts by emphasising that while globalisation brings challenges 'it is a positive force for change' (European Commission, 2017b, p. 7). While it subsequently argues that the EU should do more to ensure that trade is not only free but also fair, this should not be read as a change of policy direction. Rather, it is fully in line with the EU's long-held position that trade liberalisation needs to be accompanied with efforts to ensure that European firms and workers can compete on a level-playing field, in order to maintain sufficient domestic support for liberalisation. In its final section, the paper places the responsibility for ensuring a fairer distribution of the benefits of trade squarely in the hands of Member State governments, while reminding them of the need to make Europe more competitive. Strikingly, in contrast with the White Paper and the other reflection papers, Harnessing Globalisation does not present alternative scenarios for the future conduct of EU trade policy for stakeholders and decision-makers to choose between. The European Commission does not appear to view Brexit as a reason to fundamentally question, let alone alter, its trade strategy. On the contrary, the paper outlines a strong defence of the EU's traditionally liberal trade policy against the 'temptations of isolationism' (European Commission, 2017b, p. 12), making a clear reference to Brexit and to the 'America First' trade policy of the then recently-inaugurated US President Donald Trump.

The impact of Brexit on the trade discourse and practice of the EU is difficult to disentangle from the coterminous influence of Trump. That said, the two are often taken together by European trade policymakers as mutually reinforcing signs of a populist and isolationist trend that the EU should resist. They have also been 
jointly framed as illustrating the need for the Union to become an even more passionate global leader regarding 'free trade'. On the occasion of the 2017 State of the EU, EU Trade Commissioner Malmström has said that ' $[t]$ he world needs leaders in trade. The EU continues to champion free and fair trade, at the forefront of a group of like-minded countries' (European Commission, 2017c). In a speech at Humboldt University the following year, she stated that, in response to Brexit and Trump, '[w]e made clear where we stand-progressive, open global traders. Responsible traders. Since flying that flag, countries have [sic] are lining up with us, and our trade agenda has never been busier' (Malmström, 2018). In sum, Brexit and Trump have not been interpreted by the Commission as a call to rethink the liberal orientation of EU trade policy.

Underscoring these discursive moves, we have also seen a continuation and strengthening of the EU's liberal trade policy in practice. The Brexit vote has not prevented the conclusion of several trade agreements that were already in the pipeline, such as with Canada, Japan, Vietnam and Singapore. The framing of the referendum result and the election of Trump have put opponents of EU trade agreements in an uncomfortable position, making it more difficult for them to legitimately contest EU trade policies. Since Brexit, observers have reframed political conflict along a 'new political divide' between 'open' and 'closed' positions, thereby putting critics of trade agreements-including progressives-in the same camp as cultural nationalists such as Trump or some UK leavers (see Siles-Brügge, 2017; The Economist, 2016). Besides concluding trade agreements that had been long in the making, negotiations on new trade agreementsor to 'modernise' existing trade agreements-have also been (re-)launched since the referendum with partners such as Indonesia, Australia, New Zealand and Chile. Moreover, at the time of writing 'agreements in principle' have been reached on the modernisation of the EU-Mexico trade agreement and on a new FTA with Mercosur. Talks on these were only (re-)launched shortly before the referendum in May 2016 (European Commission, 2019a, 2019b). Finally, the Commission has even proposed (and the Council subsequently approved) re-opening limited trade talks with the US to stave off a trade war, despite a commitment made by several key EU actors including the French Government and Malmström to only negotiate trade agreements with parties to the Paris Climate Change Agreement (Beattie, 2019; Darby, 2018; European Commission, 2019c).

To conclude, in the period since Brexit, we have not seen a protectionist shift in the EU's trade discourse or policies, but rather a strengthening of its traditional liberal orientation. The European Commission has legitimised further liberalisation efforts by arguing that, now more than ever, the EU needs to be a defender of free trade that rejects the temptations of protectionism.

\section{Conclusion}

In this article, we have discussed the potential impacts of Brexit on EU trade policy. The conventional wisdom has been that the UK's withdrawal will push the EU in a less liberal policy direction. We have argued that this expectation is based on an unduly static analysis of the consequences of Brexit. We cannot simply subtract UK representation from the EU when considering the impact of Brexit on this policy area as there are several dynamic factors that might affect EU trade policy going forward. First, there is the uncertainty about the future EU-UK relationship. This affects how both institutional and societal actors respond strategically to Brexit, for example by relocating their economic activities or reconsidering their alliances or positions within EU institutions. Second, there is the matter of how Brexit is diagnosed, and how this legitimates different EU trade policy responses. Even if Brexit does not ultimately occur, the dynamic effects of uncertainty will still have had an impact.

Brexit may shape EU trade policy in counterintuitive ways. For example, a soft Brexit outcome, where the UK remains de facto in the Single Market and Customs Union while losing influence over EU decision-making, could change EU trade policy more than a hard Brexit. In the case of the former, EU leverage in trade negotiations would remain unchanged, while we might expect little relocation by UK firms which would no longer be represented by the EU in trade policy. Consequently, the EU's position could become somewhat less liberal. There might be less of a willingness to sacrifice defensive interests-such as agriculture-in order to secure offensive gains in business or financial services, with the EU retaining a similar amount of market power to defend this position. That said, this effect might be mitigated by high levels of interdependence between EU27 and UK firms. This might lead them to adopt similar positions on trade policy. A hard Brexit, meanwhile, is less likely to lead to changes in the EU's trade policy position, as firms dependent on regional and global economic integration are more likely to relocate to the EU. Cross-border service suppliers and manufacturing in transnational supply chains would retain representation in EU trade policy. All in all, whether because of continued interdependence or relocation, key pro-liberalisation interests will continue influencing EU trade policy post-Brexit. This is contrary to the expectation that Brexit will necessarily push the $\mathrm{EU}$ in a more protectionist direction.

Studying the response of EU trade policy since the referendum shows us that so far, no radical change has materialised. The EU has continued its traditional position of progressive liberalisation in discourse and practice. Rather than interpreting Brexit as a sign that EU trade policy needs a fundamental rethink, the European Commission has framed it as demonstrating the need to 'hold the line'. The Commission has even used Brexit, and the reinforcing presence of Donald Trump, to portray the EU as the champion of global free trade. 


\section{Acknowledgments}

We would like to thank the three anonymous reviewers, the Politics and Governance editorial board member, Michael Smith, Brendan Moore, Michelle Egan, Sven Van Kerckhoven, Johan Adriaensen, Hubert Zimmerman, Alasdair Young, Patricia García Durán and Katherina Meissner for their comments on earlier drafts of this article. Any errors and opinions expressed are exclusively our own. Gabriel Siles-Brügge acknowledges the support of two UK Economic and Social Research Council Impact Acceleration Accounts (grant references ES/M500434/1 and ES/T502054/1).

\section{Conflict of Interests}

The authors declare no conflicts of interests.

\section{References}

Beattie, A. (2019). Tensions rise as US turns up heat on Brussels over trade. Financial Times. Retrieved from https://www.ft.com/content/ba8c7272-17fe-11e99e64-d150b3105d21

Berry, C. (2016). Austerity politics and UK economic policy. London: Palgrave Macmillan.

Blyth, M. (2003). Structures do not come with an instruction sheet: Interests, ideas, and progress in political science. Perspectives on Politics, 1(4), 695-700.

Bollen, Y., De Ville, F., \& Orbie, J. (2016). EU trade policy: Persistent liberalisation, contentious protectionism. Journal of European Integration, 38(3), 279-294.

Bradford, A. (2012). The Brussels effect. Northwestern University Law Review, 107(1), 1-68.

Breinlich, H., Leromain, E., Novy, D., \& Sampson, T. (2019). Voting with their money: Brexit and outward investment by UK firms (Centre for Economic Performance Brexit Analysis, No. 13). London: Centre for Economic Performance. Retrieved from https://ukandeu.ac.uk/wp-content/uploads/2019/ 02/Voting-with-their-Money.pdf

Cernat, L., \& Kutlina-Dimitrova, Z. (2014). Thinking in a box: A 'mode 5' approach to service trade. Journal of World Trade, 48(6), 1109-1126.

Council of the EU. (2019). Voting calculator. Council of the European Union. Retrieved from https:// www.consilium.europa.eu/en/council-eu/votingsystem/voting-calculator

Damro, C. (2012). Market power Europe. Journal of European Public Policy, 19(5), 682-699.

Darby, M. (2018). Canada and EU add climate clause to trade pact. Euractiv. Retrieved from https://www. euractiv.com/section/climate-environment/news/ canada-and-eu-add-climate-clause-to-trade-pact

De Bièvre, D. (2018). The paradox of weakness in European trade policy: Contestation and resilience in CETA and TTIP negotiations. The International Spectator, 53(3), 70-85.
De Ville, F., \& Siles-Brügge, G. (2016). TTIP: The truth about the transatlantic trade and investment partnership. Cambridge: Polity Press.

De Ville, F., \& Siles-Brügge, G. (2018). The role of ideas in legitimating EU trade policy: From the Single Market Programme to the transatlantic trade and investment partnership. In S. Khorana \& M. García (Eds.), Handbook on the EU and international trade (pp. 243-262). Cheltenham: Edward Elgar.

De Ville, F., \& Siles-Brügge, G. (2019). The impact of Brexit on EU policies. Politics and Governance, 7(3), 1-6.

Department for Business, Innovation \& Skills. (2012). Benchmarking UK competitiveness in the global economy (BIS Economics Working Paper No. 19). London: Department for Business, Innovation \& Skills. Retrieved from https://assets.publishing.service.gov. uk/government/uploads/system/uploads/ attachment_data/file/34647/12-1207benchmarking-uk-competitiveness-in-the-globaleconomy.pdf

Egan, M. (2019). EU single market(s) after Brexit. Politics and Governance, 7(3), 19-29.

European Commission. (2015). Trade for All: Towards a more responsible trade and investment policy. Brussels: European Commission.

European Commission. (2017a). White paper on the future of Europe: Reflections and scenarios for the EU27 by 2025 (No. COM[2017] 2025). Brussels: European Commission.

European Commission. (2017b). Reflection Paper on Harnessing Globalisation (No. COM[2017] 240). Brussels: European Commission.

European Commission. (2017c). State of the Union 2017-Trade package: Commission unveils initiatives for a balanced and progressive trade policy. Brussels: European Commission.

European Commission. (2019a). Countries and regions: Mexico. European Commission. Retrieved from http://ec.europa.eu/trade/policy/countries-andregions/countries/mexico

European Commission. (2019b). Countries and regions: Mercosur. European Commission. Retrieved from http://ec.europa.eu/trade/policy/countries-andregions/regions/mercosur

European Commission. (2019c). EU-U.S. trade: Commission welcomes Council's green light to start negotiations with the United States. European Commission. Retrieved from http://trade.ec.europa.eu/ doclib/press/index.cfm?id $=2010$

European Parliament. (2018). Table. European Parliament. Retrieved from http://www.europarl.europa. eu/resources/library/media/20180123RES92302/ 20180123RES92302.pdf

Evenett, S. J., \& Vermulst, E. (2005). The politicisation of EC anti-dumping policy: Member states, their votes and the European commission. The World Economy, 25(5), 701-717. 
Frantescu, D. P. (2015). Top 5 likely effects of Brexit on EU's policies. Votewatch.eu. Retrieved from https://www.votewatch.eu/blog/top-5-likelyeffects-of-brexit-on-eus-policies

Froud, J., Johal, S., Law, J., Leaver, A., \& Williams, K. (2011). Rebalancing the economy (or buyer's remorse) (Centre for Research on Socio-Cultural Change Working Paper No. 87). Retrieved from http://hummedia.manchester.ac.uk/institutes/cresc/ workingpapers/wp87.pdf

Gheyle, N., \& De Ville, F. (2017). How much is enough? Explaining the continuous transparency conflict in TTIP. Politics and Governance, 5(3), 16-28.

Hay, C. (2011). Pathology without crisis? The strange demise of the anglo-liberal growth model. Government and Opposition, 46(1), 1-31.

Henig, D. (2018). A Brexit probability index: Tracking what will happen next. Prospect. Retrieved from https://www.prospectmagazine.co.uk/politics/abrexit-probability-index-tracking-what-will-happennext

Hestermeyer, H., \& Ortino, F. (2016). Toward a UK trade policy post-Brexit: The beginning of a complex journey. King's Law Journal, 27(3), 452-462.

Hotten, R. (2019). Brexit: Car investment halves as industry hits 'red alert'. BBC News. Retrieved from https:// www.bbc.co.uk/news/business-47055188

Howarth, D., \& Quaglia, L. (2017). Brexit and the single European financial market. Journal of Common Market Studies, 55(S1), 149-164.

International Trade Committee. (2018). Continuing application of EU trade agreements after Brexit (Report No. HC 520). London: UK Parliament.

International Trade Committee. (2019). Oral evidence: Trade in services (No. HC 1776). London: UK Parliament.

Jacobs, F. B. (2018). The EU after Brexit: Institutional and policy implications. London: Palgrave Macmillan.

James, S., \& Quaglia, L. (2019). Brexit, the city and the contingent power of finance. New Political Economy, 24(2), 258-271.

Jensen, M., \& Snaith, H. (2018). Brexit and the European Union: Hanging in the balance? In P. Diamond, P. Nedergaard, \& B. Rosamond (Eds.), The Routledge handbook of the politics of Brexit (pp. 254-265). Abingdon: Routledge.

Khan, M. (2018). EU's new hanseatic league picks its next battle. Financial Times. Retrieved from https://www.ft.com/content/aedbe32a-8af7-11e8bf9e-8771d5404543

Khorana, S., \& García, M. (2018). Introduction to the handbook on the EU and international trade. In S. Khorana \& M. García (Eds.), Handbook on the EU and international trade (pp. 1-16). Cheltenham: Edward Elgar.

Larsen, H. (2018). Brexit and the EU as an international actor. In P. Diamond, P. Nedergaard, \& B. Rosamond (Eds.), The Routledge handbook of the politics of
Brexit (pp. 223-232). Abingdon: Routledge.

Lavery, S., Quaglia, L., \& Dannreuther, C. (2019). The political economy of Brexit and the future of British capitalism: First symposium. New Political Economy, 24(2), 252-257.

Lietaert, M. (2009). New strategy, new partnership: EU Commission and the city of London in trade in services policy. Paper presented at the Political Studies Association Annual Conference, Manchester, UK.

Lowe, S. (2018a). An effective UK trade policy and a customs union are compatible. Centre for European Reform (CER) Insight. Retrieved from https://www. cer.eu/publications/archive/bulletin-article/2018/ effective-uk-trade-policy-and-customs-union-are

Lowe, S. (2018b). Brexit and services: How deep can the UK-EU relationship go? London: Centre for European Reform. Retrieved from https://www.cer.eu/sites/ default/files/brexit_trade_sl_pbrief_6.12.18.pdf

Malmström, C. (2018). Transforming trade. Brussels: European Commission. Retrieved from http:// trade.ec.europa.eu/doclib/docs/2018/october/ tradoc_157443.pdf

Manger, M. (2009). Investing in protection: The politics of preferential trade agreements between North and South. Cambridge: Cambridge University Press.

Meunier, S. (2014). Divide and conquer? China and the cacophony of foreign investment rules in the EU. Journal of European Public Policy, 21(7), 996-1016.

Meunier, S., \& Nicolaïdis, K. (2006). The European Union as a conflicted trade power. Journal of European Public Policy, 13(6), 906-925.

Morris, S. (2019, March 20). UK to lose $f 1$ th of financial assets to Europe due to Brexit. Financial Times. Retrieved from https://www.ft.com/content/ 016171be-4a74-11e9-8b7f-d49067e0f50d

Nielsen, J. U.-F., \& Svendsen, G. T. (2012). EU lobbying and anti-dumping policy. Journal of World Trade, 46(1), 187-212.

Oliver, C., \& Spiegel, P. (2014, October 22). EU states tell Juncker not to water down trade deal. Financial Times. Retrieved from https://www.ft.com/content/ e1dac340-59e1-11e4-9787-00144feab7de

Perraton, J., \& Spreafico, M. R. M. (2019). Paying our way in the world? Visible and invisible dangers of Brexit. New Political Economy, 24(2), 272-285.

Roederer-Rynning, C. (2017). Parliamentary assertion and deep integration: The European parliament in the CETA and TTIP negotiations. Cambridge Review of International Affairs, 30(5/6), 507-526.

Roederer-Rynning, C., \& Matthews, A. (2019). What Common Agricultural Policy after Brexit? Politics and Governance, 7(3), 40-50.

Romei, V., \& Jackson, G. (2019, June 10). Brexit uncertainty drives investment boost for other EU countries. Financial Times. Retrieved from https:// www.ft.com/content/93c681ca-7c9c-11e9-81d2f785092ab560

Schneider-Petsinger, M. (2019). US-EU trade relations 
in the Trump era: Which way forward? London: Chatham House. Retrieved from https://www. chathamhouse.org/sites/default/files/publications/ research/2019-03-08US-EUTradeRelations2.pdf

Seabrooke, L., \& Wigan, D. (2017). Brexit and global wealth chains. Globalizations, 14(6), 820-829.

Serwicka, I., \& Tamberi, N. (2018). Not backing Britain: FDI inflows since the Brexit referendum (UK Trade Policy Observatory Briefing Paper No. 23). London: Chatham House. Retrieved from http://blogs.sussex. ac.uk/uktpo/files/2018/10/BP23interactive.pdf

Siles-Brügge, G. (2013). The power of economic ideas: A constructivist political economy of EU trade policy. Journal of Contemporary European Research, 9(4), 597-617.

Siles-Brügge, G. (2017). Transatlantic investor protection as a threat to democracy: The potency and limits of an emotive frame. Cambridge Review of International Affairs, 30(5/6), 464-488.

Smith, M. (2019). The European Union and the global arena: In search of post-Brexit roles. Politics and Governance, 7(3), 83-92.

The Economist. (2016, July 30). The new political divide. The Economist. Retrieved from https:// www.economist.com/leaders/2016/07/30/the-newpolitical-divide

Trommer, S. (2017). Post-Brexit trade policy autonomy as pyrrhic victory: Being a middle power in a contested trade regime. Globalizations, 14(6), 810-819.
Van Loon, A. (2018). Diverging German and British governmental trade policy preferences in the Transatlantic Trade and Investment Partnership (TTIP) negotiations. Journal of Contemporary European Studies, 26(2), 165-179.

VoteWatch Europe. (2018). The policy implications of the proposed post-Brexit seats redistribution in the European Parliament. Votewatch.eu. Retrieved from https://www.votewatch.eu/blog/the-policyimplications-of-the-proposed-post-brexit-seatsredistribution-in-the-european-parliament

Woolcock, S. (2015). Trade policy: policy-making after the Treaty of Lisbon. In H. Wallace, M. A. Pollack, \& A. R. Young (Eds.), Policy-making in the European Union (7th ed., pp. 388-406). Oxford: Oxford University Press.

Young, A. R. (2017a). The new politics of trade: Lessons from TTIP. Newcastle: Agenda.

Young, A. R. (2017b). Trade policy in a changing EU and an uncertain world. Paper presented at the 'Jean Monnet Fellowship Programme @ 25' Alumni Conference, European University Institute, Florence, Italy.

Young, A. R., \& Peterson, J. (2014). Parochial global Europe: 21st century trade politics. Oxford: Oxford University Press.

Zimmermann, H. (in press). Brexit and the external trade policy of the EU. European Review of International Studies, 6(1).

\section{About the Authors}

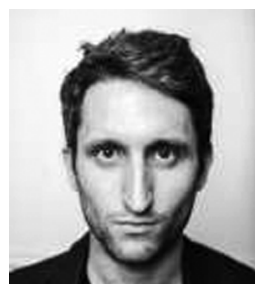

Ferdi De Ville is Associate Professor in European Politics at Ghent University. His research focuses on the political economy of European integration, and of EU trade policy in particular. He is the coauthor (with Gabriel Siles-Brügge) of TTIP: The Truth about the Transatlantic Trade and Investment Partnership (2016, Polity) and (with Mattias Vermeiren) of Rising Powers and Economic Crisis in the Euro Area (2016, Palgrave). He tweets under @FerdiDeVille.

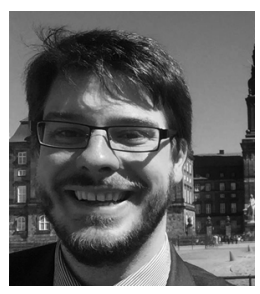

Gabriel Siles-Brügge is Associate Professor in Public Policy at the University of Warwick. His current research focuses on the municipal-level contestation of trade and investment agreements, the role of emotion in trade and investment policy and the political economy of Brexit. He is the author of Constructing European Union Trade Policy (2014, Palgrave Macmillan) and co-author (with Ferdi De Ville) of TTIP: The Truth about Transatlantic Trade and Investment Partnership (2016, Polity). He is a Scientific Advisor on trade and investment policy to the European Public Health Alliance and was a Parliamentary Academic Fellow with the UK House of Commons International Trade Committee from 2017-19. He tweets under @GabrielSilesB. 